\title{
Functional Attributes of Psychrotolerant Rhizobacteria from Wheat (Triticum aestivum L.) Rhizoshpere
}

\author{
Aamni Singh $^{1}$ and Veena Khanna ${ }^{2 *}$ \\ ${ }^{1}$ Department of Microbiology, Punjab Agricultural University, Ludhiana - 141001, Punjab, India \\ ${ }^{2}$ Department of Plant Breeding and Genetics, Punjab Agricultural University, \\ Ludhiana - 141001 Punjab, India \\ *Corresponding author
}

\begin{tabular}{|l|}
\hline K e y w or d s \\
PGPR, Rhizobacteria, \\
$\begin{array}{l}\text { Wheat, Zinc } \\
\text { solubilizers. }\end{array}$ \\
\hline Article Info \\
\hline $\begin{array}{l}\text { Accepted: } \\
\text { 17 September } 2017 \\
\text { Available Online: } \\
\text { 10 November } 2017\end{array}$ \\
\hline
\end{tabular}

\section{A B S T R A C T}

Cold-tolerant PGPRs are known to improve plant growth and nutrient uptake by an array of mechanisms, under stress and nutrient imbalance conditions. On the basis of growth potential we selected 43 PGPRs from pool of 85 rhizobacterial isolates obtained from wheat rhizospheric soil collected from different wheat growing fields. Phosphate and zinc solubilization efficiency along with phytohormones and siderophore producing ability at 10 and $20^{\circ} \mathrm{C}$ was also assessed. Rhizobacterial isolates A-43, A-13, A-12, A-36, A-25, A22 and A-34 was potent phosphate and zinc solubilizers. IAA production was estimated in the range from 2.12 to $43.24 \mu \mathrm{g} / \mathrm{ml}$ and 2.40 to $68.36 \mu \mathrm{g} / \mathrm{ml}$ in the presence of tryptophan at 10 and $20^{\circ} \mathrm{C}$ respectively. Maximum GA production was recorded with A-43, A-13, A12 and A-25 at 10 and $20^{\circ} \mathrm{C}$. Similarly highest siderophore production was shown by bacterial culture A-6 $(250.4 \mu \mathrm{g} / \mathrm{ml}$ and $90.5 \mu \mathrm{g} / \mathrm{ml})$ and A-43 $(225.9 \mu \mathrm{g} / \mathrm{ml}$ and 80.6 $\mu \mathrm{g} / \mathrm{ml}$ ) at both temperatures. Also, isolates A-43, A-36, A-13 and A-12 were resistant to many antibiotics like ampicillin $(25 \mu \mathrm{g} / \mathrm{disc})$, tetracycline $(10 \mu \mathrm{g} / \mathrm{disc})$, streptomycin $(10$ $\mu \mathrm{g} / \mathrm{disc})$ etc. These four potent rhizobacterial isolates improved germination, root and shoot length and fresh weight of wheat seedlings as compared to uninoculated control under axenic conditions.

\section{Introduction}

Wheat (Triticum aestivum L.) is a major cereal crop that sustains humanity and it is the staple food of more than $40 \%$ of human population. India is the second largest producer of wheat (94.90 million tons) next only to China (125.60 million tons) and covers the largest area under its cultivation (29.80 $\mathrm{m} \mathrm{ha}$ ), which is about $13.53 \%$ of the world wheat area (217 m ha) (FAOSTAT 2014). The most favorable climatic condition for wheat cultivation is cold temperature during the vegetative growth period followed by warm temperature for the grain to mature and ripen.

The plant growth promoting rhizobacteria (PGPR) facilitates plant growth and development with a spectrum of direct and indirect mechanisms under stress and nonstress conditions (Nadeem et al., 2014). The rhizobacteria affect plant growth directly by increasing nutrient cycling, biological nitrogen fixation (Ahmad et al., 2008), siderophore production, solubilization of 
phosphorus and zinc, synthesis of phytohormones or indirectly by synthesis of biocontrol compounds to inhibit phytopathogens (Lucy et al., 2004).

Nutrient deficiency in addition to various abiotic (cold temperature) and biotic stress is one of the important yield limiting factor in wheat. To overcome micronutrient deficiency, improvement of $\mathrm{Zn}$ bioavailability in cultivated soils may improve crop growth and also enhance $\mathrm{Zn}$ contents in the staple food grains which would possibly diminish major health risks. Also, Biofortification is a current approach aimed at increasing the bioavailability of micronutrients such as $\mathrm{Zn}$ and $\mathrm{Fe}$ in the staple crops of specific region (Stein, 2010).

In order to improve plant microbe interaction under low temperature conditions, it is essential to exploit cold adapted strains of rhizospheric bacteria that can influence plant growth and development. Psychrotolerant PGPRs are widespread in the agro-ecosystem and play a range of roles including plantgrowth-promotion, micronutrient solubilisation and alleviation of cold stress in plants.

Bioinoculants for the improvement of micronutrient deficiency is promising due to its ecological, economic, and eco-friendly nature. So, keeping this in view present study deals with the characterization of low temperature tolerant rhizobacterial isolates for their multiple plant growth promoting traits at low temperature from the rhizosphere of wheat crop.

\section{Material and Methods}

\section{Isolation of rhizobacteria}

All the isolates of Pseudomonas, Bacillus and Serratia were isolated from the 27 wheat rhizoshperic soil samples by standard microbiological techniques collected from different locations of Punjab, Himachal Pradesh, Haryana and U.P., India. Spread plating was done on Nutrient agar (NA) for Bacillus and Serratia and on King's B for Pseudomonas (King et al., 1954). The isolates were grown at $10^{\circ} \mathrm{C}$ and $20^{\circ} \mathrm{C}$ in respective media and growth in terms of optical density was recorded at $600 \mathrm{~nm}$. Isolates showing maximum growth both at $10^{\circ} \mathrm{C}$ and $20^{\circ} \mathrm{C}$ were selected for further analysis. All the functionality traits were assessed at $10^{\circ} \mathrm{C}$ and $20^{\circ} \mathrm{C}$.

\section{In vitro screening of bacterial isolates for their plant growth promoting activities}

\section{Zn solubilisation}

Qualitative assay for $\mathrm{Zn}$ solubilisation: All the bacterial isolates were first screened by plate assay for their efficiency to solubilize zinc on Tris-minimal medium supplemented separately with zinc oxide $(\mathrm{ZnO})[1.244 / \mathrm{L}]=$ $15.23 \mathrm{mM}$ and zinc carbonate $\left(\mathrm{ZnCO}_{3}\right)$ $[1.9882 \mathrm{~g} / \mathrm{L}]=5.0 \mathrm{mM}$ at a concentration equivalent to $0.1 \% \mathrm{Zn}$ (Fasim et al., 2002). Zinc solubilization efficiency (SE) was calculated as described by Ramesh et al., (2014).

$\mathrm{SE}=\frac{\frac{\text { Diameter } \quad \text { of } \text { solubiliza } \quad \text { tion halo zone }}{\text { Diameter of colony }}}{\times 100}$

Effect of Zinc compounds on $\mathrm{pH}$ of the medium: Bacterial isolates showing zones of clearance with $\mathrm{ZnO} /\left(\mathrm{ZnCO}_{3}\right)$ on solid medium were inoculated in minimal medium, supplemented with the same compounds $(1 \mathrm{mg} / \mathrm{ml}$, each) and glucose $(10 \mathrm{mg} / \mathrm{ml})$.

Inoculated flasks were incubated at 10 and $20^{\circ} \mathrm{C}$ for 3 to 5 days and samples were drawn at regular interval to record $\mathrm{pH}$ of culture broth (Joshi et al., 2013). 


\section{Phosphate-solubilization}

All the isolates were screened on Pikovskaya's agar plates and NBRI-BPB medium described by Mehta and Nautiyal (2001) for phosphate solubilising. The solubilization index was calculated by EdiPremono et al., (1996)

$\begin{aligned} & \text { Phosphate Solubilization Index } \\ & \text { Total diameter (colony }+ \text { halo zone) }\end{aligned}$
Diameter of colony

Quantitatively P-solubilization was recorded at intervals of 3 days up to 15 days of incubation (Jackson, 1973).

\section{IAA and gibberellic acid production}

Characterization of isolates for the production of IAA and gibberellic acid was determined as per the method given by Gordon and Weber (1951) and Borrow et al., (1955) respectively.

\section{Production of siderophore}

Siderophore production of isolates was done both qualitatively and quantitatively as per the method described by Schwyn and Neilands (1987) and Arnow (1937) respectively.

\section{Intrinsic antibiotic resistance spectra}

An antibiotic resistance spectrum of the isolates was studied by using different antibiotics.

Filter paper discs (Hi-Media) containing a standard concentration of antibiotics viz. ampicillin $\quad(25 \mu \mathrm{g} / \mathrm{disc}), \quad$ chloramphenicol $(25 \mu \mathrm{g} / \mathrm{disc}), \quad$ tetracycline $\quad(30 \mu \mathrm{g} / \mathrm{disc})$, streptomycin $\quad(25 \mu \mathrm{g} / \mathrm{disc}), \quad$ streptomycin $(10 \mu \mathrm{g} / \mathrm{disc}), \quad$ carbenicillin $\quad(100 \mu \mathrm{g} / \mathrm{disc})$, kanamycin $(30 \mu \mathrm{g} / \mathrm{disc})$ and tetracycline $(30 \mu \mathrm{g} / \mathrm{disc})$ were used.

\section{Germination of wheat seeds under axenic} conditions

Germination tests were carried out to determine the effect of potent rhizobacterial isolates on germination and seedling growth of wheat variety (WH1105) under axenic conditions as per the method of described Khalid et al., (2004).

\section{Results and Discussion}

\section{Isolation and characterization}

A total 85 rhizobacterial isolates were isolated from wheat rhizospheric soil from 27 different wheat growing fields. Isolates 40 from Kings $\mathrm{B}$ medium showed the characteristic yellowish-green pigmentation and 41 isolates from NA showed transparent to creamish, yellow to orange in color and 4 isolates from NA showed an entire margin and produced red color pigmentation. On the basis of cultural morphological and biochemical tests, these were tentatively assigned to genera Bacillus, Pseudomonas, and Serratia.

The growth in terms of optical density recorded at $10^{\circ} \mathrm{C}$ and $20^{\circ} \mathrm{C}$ showed that rhizobacterial isolates exhibited growth potential at both $10^{\circ} \mathrm{C}$ and $20^{\circ} \mathrm{C}$ when incubated for 24 hours. Isolates A-1, A-40, A43, A-13, A-12, A-36 and A-25 showed relatively good growth at $10^{\circ} \mathrm{C}$ however, it was lower than that at $20^{\circ} \mathrm{C}$ (Fig. 1 and 2).

\section{Zinc solubilization}

Forty three of the rhizobacterial isolates produced distinct halo zone on Tris-minimal medium supplemented with $0.1 \% \mathrm{ZnO}$ and $\mathrm{ZnCO}_{3}$ indicating zinc solubilization at $28^{\circ} \mathrm{C}$. They also showed clear halo zone on modified PVK medium supplemented with $\mathrm{ZnO}$ (Plate 1), formation of halo zone 
initiated after 2 days, reaching a maximum upto 15 days. Out of these, 38 rhizobacterial isolates showed zinc solubilization at $20^{\circ} \mathrm{C}$ and 14 isolates at $10^{\circ} \mathrm{C}$.

In plate assay, all the selected isolates could effectively solubilize the insoluble $\mathrm{Zn}$ compounds at 10 and $20^{\circ} \mathrm{C}$. At $10^{\circ} \mathrm{C}$, size of the solubilization zone ranged from 0.5 to $1.45 \mathrm{~cm}$ in $\mathrm{ZnO}$ incorporated medium (Plate 2). The formation of halo by the microorganisms is reported to be due to the movement of acidity corresponding with the solubilization of the metal compound (Saravanan et al., 2003). The S.E. ranged from 100 to 290 (Table 1). Maximum solubilization was exhibited by four isolates A-12 $($ S.E. $=290)$ followed by A-43 (S.E. = 280), A-36 (S.E. = 260) and A-13 (S.E. = 240) in $\mathrm{ZnO}$ amended media. Whereas at $20^{\circ} \mathrm{C}$ size of the halo zone ranged from 0.31 to $2.9 \mathrm{~cm}$ and S.E. $=42.86$ to 966.67 . Maximum halo zone diameter was shown by A-43, 13 (2.9), A-36, 34 (2.7), A-22 (2.6) and A-12 (2.3) respectively, (Plate 3) and maximum solubilisation shown by isolate A43 (S.E. = 966.67) followed by A-36 (S.E. = 675), A-13 (S.E. = 580) and A-12 (S.E. = 575). On average, four rhizobacterial isolate A-43, A-13, A-36, and A-12 showed zinc solubilization at both temperatures. However, their solubilization potential was more at $20^{\circ} \mathrm{C}$.

The zone of solubilization was comparatively higher in $\mathrm{ZnO}$ amended medium as compared to $\mathrm{ZnCO}_{3}$. At $10^{\circ} \mathrm{C}$, the size of the solubilization zone ranged from 0.5 to $1.45 \mathrm{~cm}$ in zinc carbonate supplemented medium. The range of S.E. (90 to 280) was found to be less as compared to zinc oxide. Maximum solubilisation was shown by isolates A-12 $($ S.E. $=280)$ which was same as in zinc oxide followed by A-43 (S.E. = 260), A-36 (S.E. = 260) (Table 1). However, isolate A-13 showed higher solubilization of zinc carbonate as compared to zinc oxide. Whereas, at $20^{\circ} \mathrm{C}$ size of the halo zone ranged from 0.5 to $2.8 \mathrm{~cm}, \mathrm{~S} . \mathrm{E}$. $=35.71$ to 800 . Maximum solubilisation showed by isolate A43 (S.E. = 800) and A-36 (S.E. = 625) which is somewhat similar to zinc oxide. However, S.E. $=733.33$ by isolate $\mathrm{A}-13$ and S.E. $=$ 583.33 by A-12 was found to be higher in the zinc carbonate medium. On average, rhizobacterial isolates A-43, A-36 and A-13 were found to be potent zinc solubilizers in zinc oxide as compared to zinc carbonate amended media at $20^{\circ} \mathrm{C}$. The result showed varied solubilization potential among the bacterial isolates in term of zinc compounds. This might be related to differences in the locations from which they were isolated.

Eight of the culture filtrates showed a drop in $\mathrm{pH}$ after 10 days growth. A significant $\mathrm{pH}$ drop from $\mathrm{pH} 7.0$ by some rhizobacteria in the uninoculated medium was observed. The $\mathrm{pH}$ drop ranged from 7 to 6.06 at $10^{\circ} \mathrm{C}$ and 7 to 3.73 at $20^{\circ} \mathrm{C}$. Among ten isolates, A-43 showed a drop in $\mathrm{pH}$ from 7.0 to 3.73 followed by A-25 (pH 4.36), A-13 (pH 5) and A-36 (pH 5.16), in zinc oxide supplemented cultures at $20^{\circ} \mathrm{C}$ (Fig. 3). Similar findings were also reported by Desai et al., (2012), they inferred that higher availability of $\mathrm{Zn}$ is directly proportional to the acidic $\mathrm{pH}$ of the medium, which was positively correlated with the production of organic acids.

Surprisingly, isolates A-36 and A-12 showed an increase in $\mathrm{pH}$ from 7 to 7.52 at $10^{\circ} \mathrm{C}$. In some potent strains, $\mathrm{pH}$ did not fall drastically thereby suggesting that in those strains other mechanisms may be active and this aspect is being accentuated. Goteti et al., (2013) in their studies also found no significant correlation between $\mathrm{pH}$ and solubilization of nutrients.

The overall result showed that maximum solubilization occurred in the presence of zinc 
oxide supplemented media at $20^{\circ} \mathrm{C}$ as compared to zinc carbonate and A-43, A-36, A-13, A-12, A-22, and A-34 were promising isolates in terms of $\mathrm{Zn}$ solubilization.

\section{Phosphate solubilization}

Screening of 85 isolates showed that 43 were phosphate solubilizers as evidenced by orangish yellow halos on NBRI-BPB media at $28^{\circ} \mathrm{C}$. Screening of $\mathrm{P}$-solubilizing ability at low temperature revealed of the 43 bacterial isolates from wheat rhizosphere 35 solubilized phosphate at $10^{\circ} \mathrm{C}$ and 38 at $20^{\circ} \mathrm{C}$.

On the basis of solubilization index, ten isolates were further selected for quantitative estimation. At $10^{\circ} \mathrm{C}$, P-solubilization on Pikovskaya's agar medium started on the 4th day and increased upto $15^{\text {th }}$ day. Maximum solubilization index was shown by isolate A43 (4.5) followed by A-25, 12 (4.3) and A-13 (4.1). Whereas, at $20^{\circ} \mathrm{C}$ solubilization started a day earlier and increased upto $15^{\text {th }}$ day. Maximum solubilization index was found in isolate A-15 (6.6) followed by A-43(6.4), A13 (6.2) and A-12 (6.1) (Table 2 and 3).

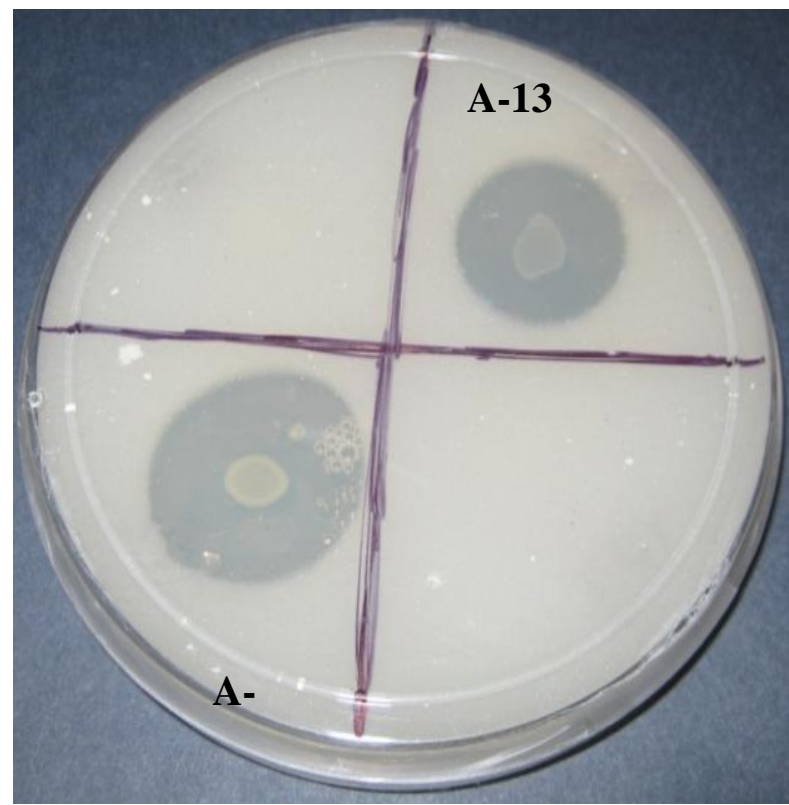

Plate.1 Zinc solubilization on modified PKV medium at $28^{\circ} \mathrm{C}$
All the isolates efficiently released the bound phosphate from calcium in the PVK broth at $10^{\circ} \mathrm{C}$ and $20^{\circ} \mathrm{C}$. The relative efficiency of 10 isolates in solubilizing TCP was evaluated in vitro as a function of time. It was seen that increasing amount of $\mathrm{P}$ was released by most of the isolates till the 9th day at $10^{\circ} \mathrm{C}$ and $6^{\text {th }}$ day at $20^{\circ} \mathrm{C}$ thereafter it started decreasing with incubation. This may be due to utilization of released $\mathrm{P}$ by rhizobacteria. The phosphate solubilization ranged from 0.4 to $11.4 \mathrm{mg} / 100 \mathrm{ml}$ at $10^{\circ} \mathrm{C}$ and 3.2 to 23.7 $\mathrm{mg} / 100 \mathrm{ml}$ at $20^{\circ} \mathrm{C}$. Maximum solubilization at $10^{\circ} \mathrm{C}$ was by isolate $\mathrm{A}-25(13.1 \mathrm{mg} / 100 \mathrm{ml})$ after 9 days of incubation followed by A-13, A-12, A-36, A-34 and A-29 (10.5 to 7.8 $\mathrm{mg} / 100 \mathrm{ml}$ ) (Table 2). Rhizobacterial isolate A-43 was potent solubilizer and showed efficient solubilization $11.4 \mathrm{mg} / 100 \mathrm{ml}$ after 6 days. Surprisingly, isolate A-3 started solubilization of phosphorus on $3^{\text {rd }}$ day itself $(3.7 \mathrm{mg} / 100 \mathrm{ml})$ and showed a decline thereafter. Isolate A-29 (6.6 mg/100 ml) found to be maximum solubilizer after 12 days and two isolates A-6 $(7.4 \mathrm{mg} / 100 \mathrm{ml})$, A-15 (6.1 mg/100 ml) after 15 days of incubation.

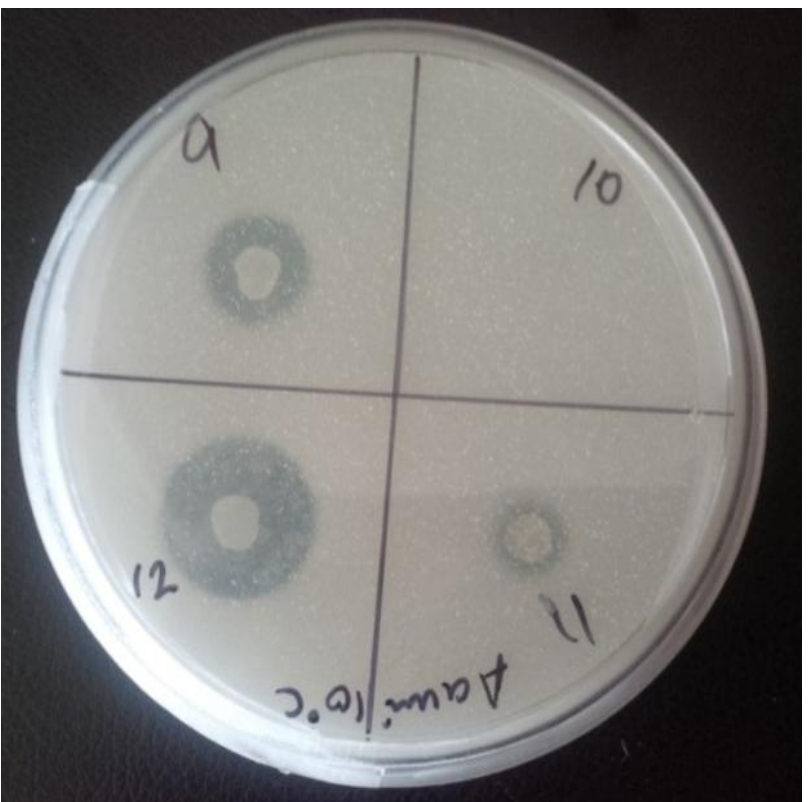

Plate.2 Zinc solubilization on Trisminimal medium $\left(0.1 \% \mathrm{ZnCO}_{3}\right)$ at $10^{\circ} \mathrm{C}$ 
Plate.3 Zinc solubilization on Tris-minimal medium $(0.1 \% \mathrm{ZnO})$ at $20^{\circ} \mathrm{C}$

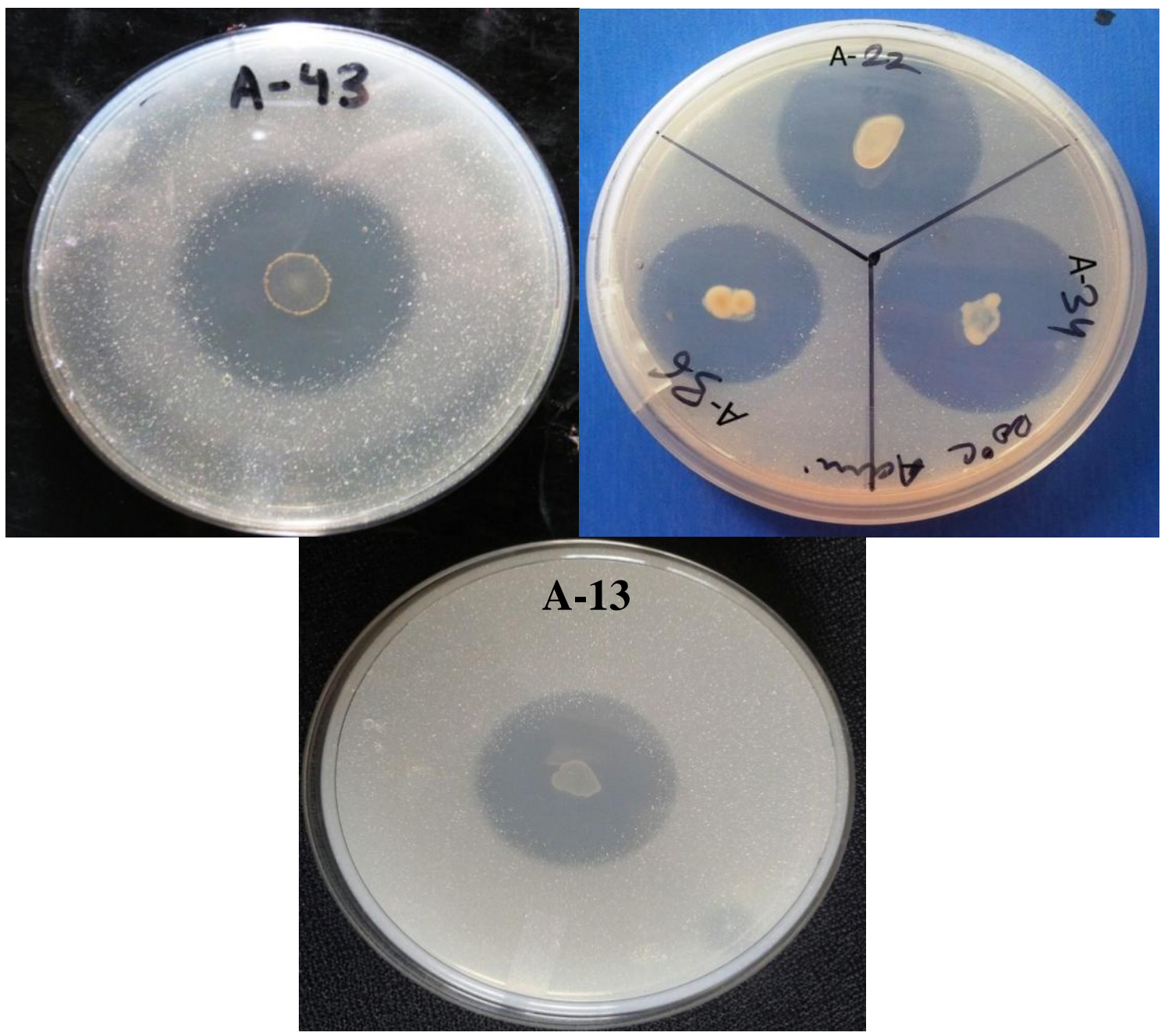

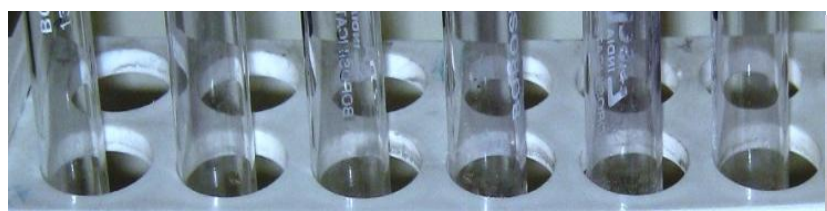
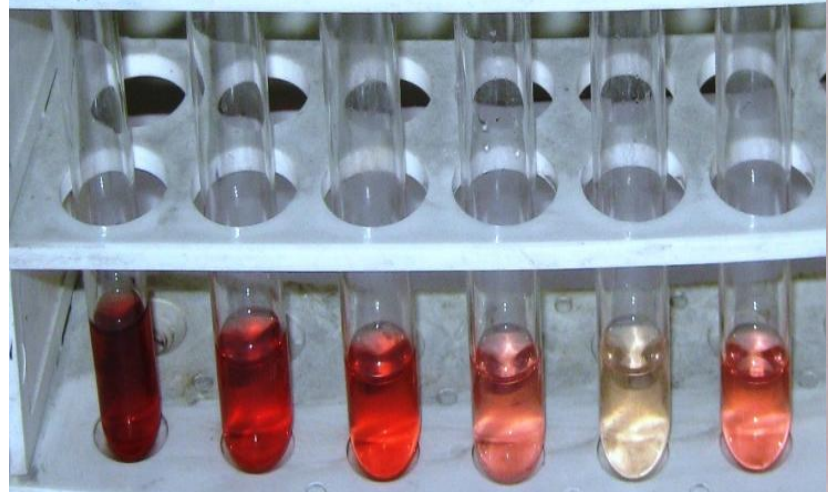

Plate.4 IAA production at 10 and $20^{\circ} \mathrm{C}$

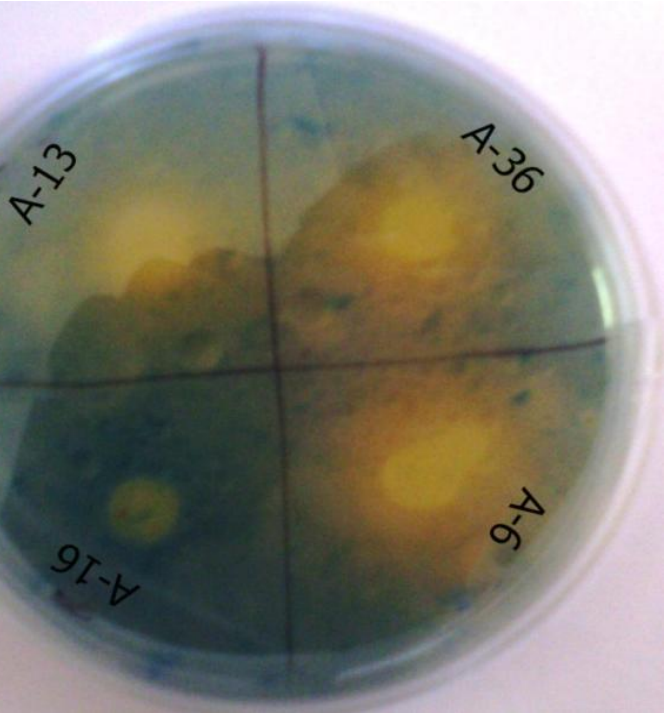

Plate.5 Siderophore production by rhizobacterial isolates $20^{\circ} \mathrm{C}$ 
Plate.6 Effect of potent rhizobacterial isolates on germination and seedling growth of wheat under axenic conditions

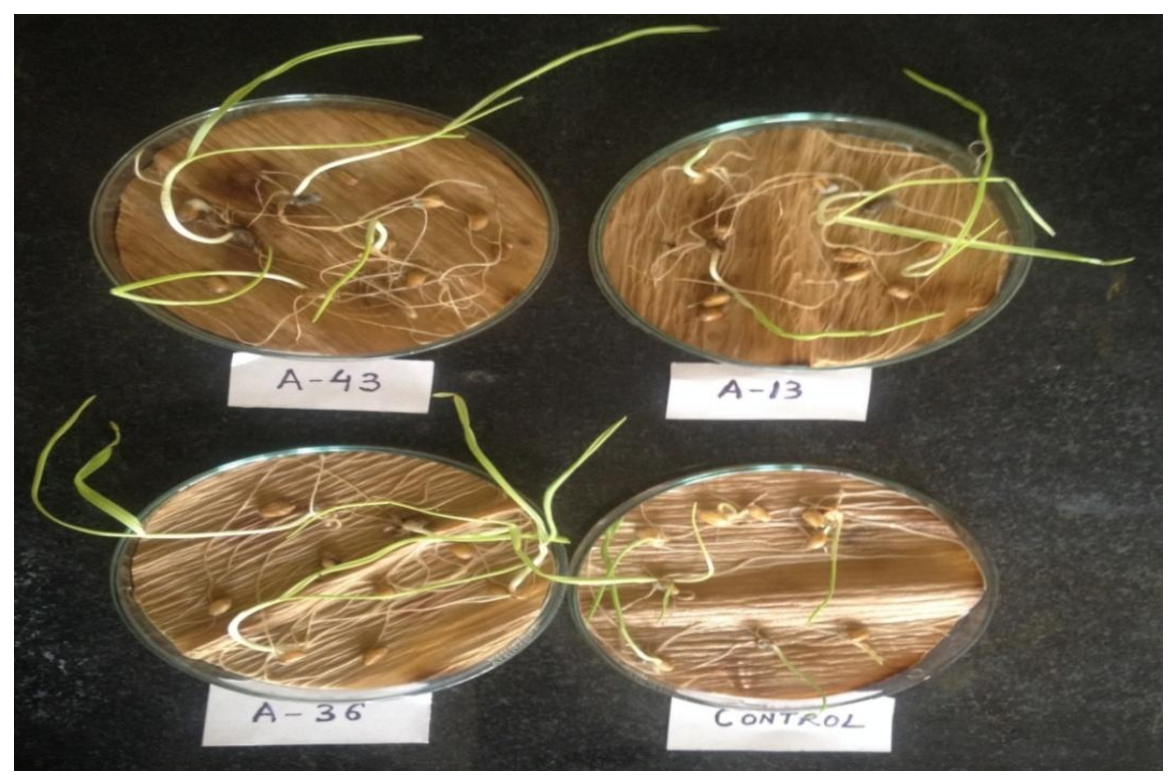

Fig.1 Growth profile of rhizobacterial isolates at $10{ }^{\circ} \mathrm{C}$

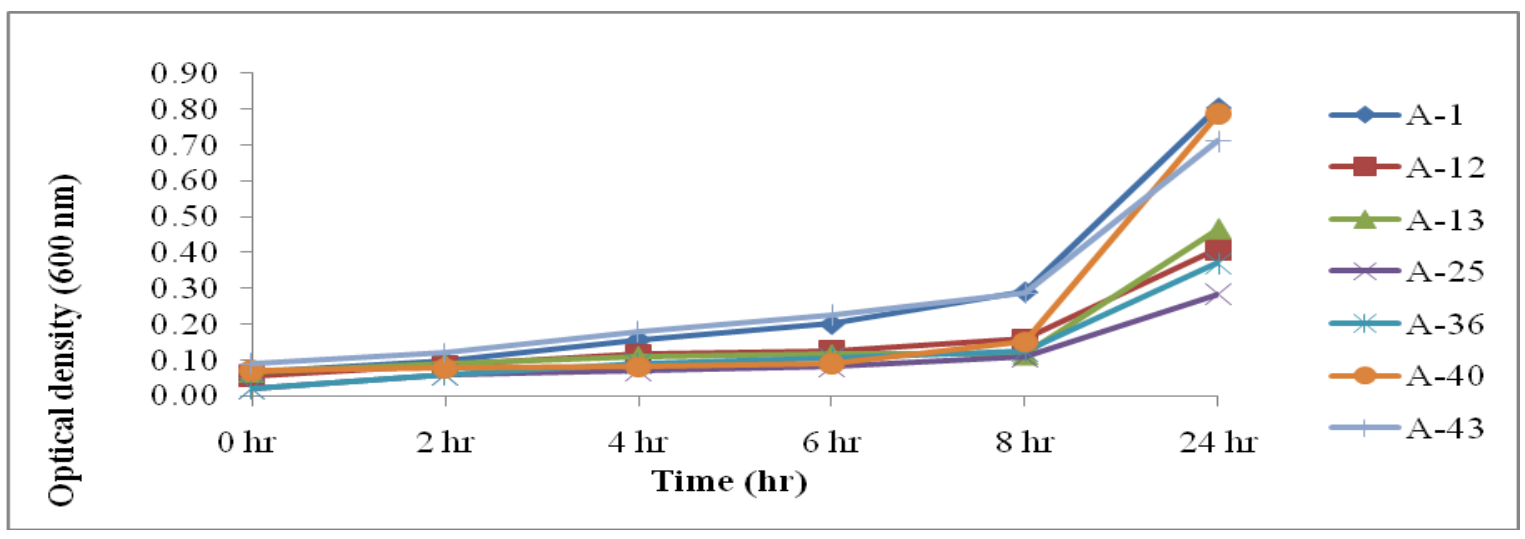

Fig. 2 Growth profile of rhizobacterial isolates at $20^{\circ} \mathrm{C}$

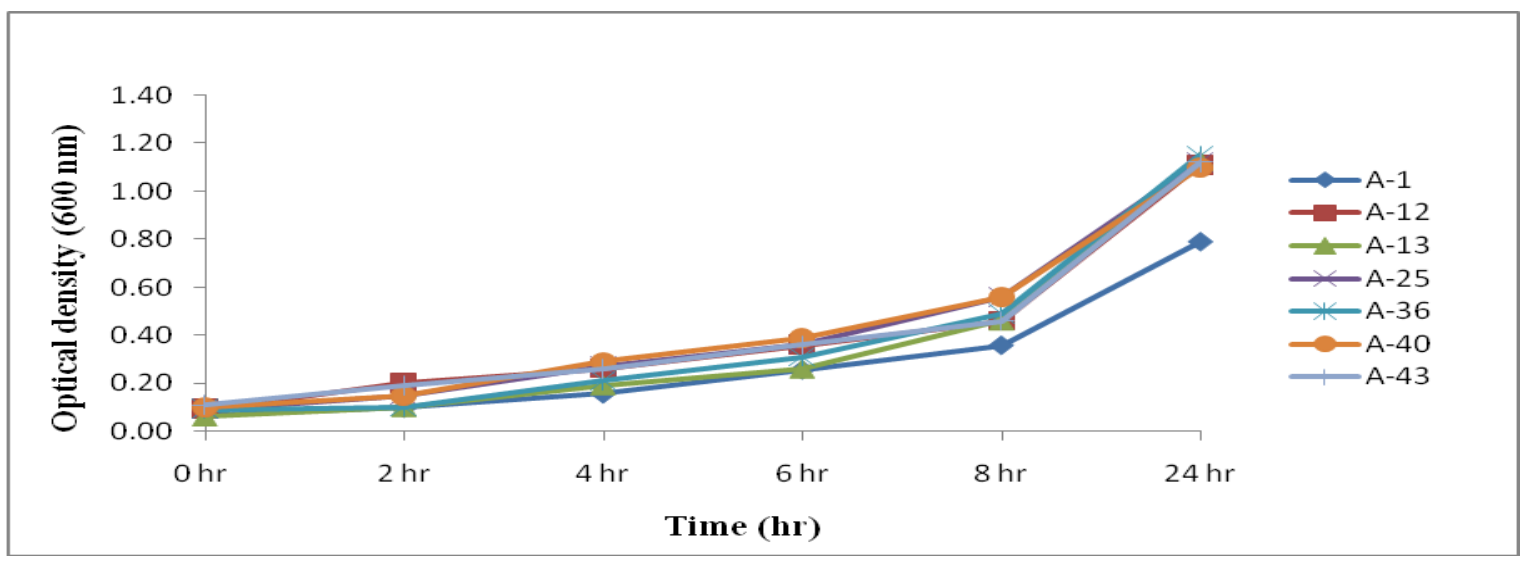


Fig.3 Relative changes in $\mathrm{pH}$ in zinc oxide supplemented medium by different zinc solubilizers

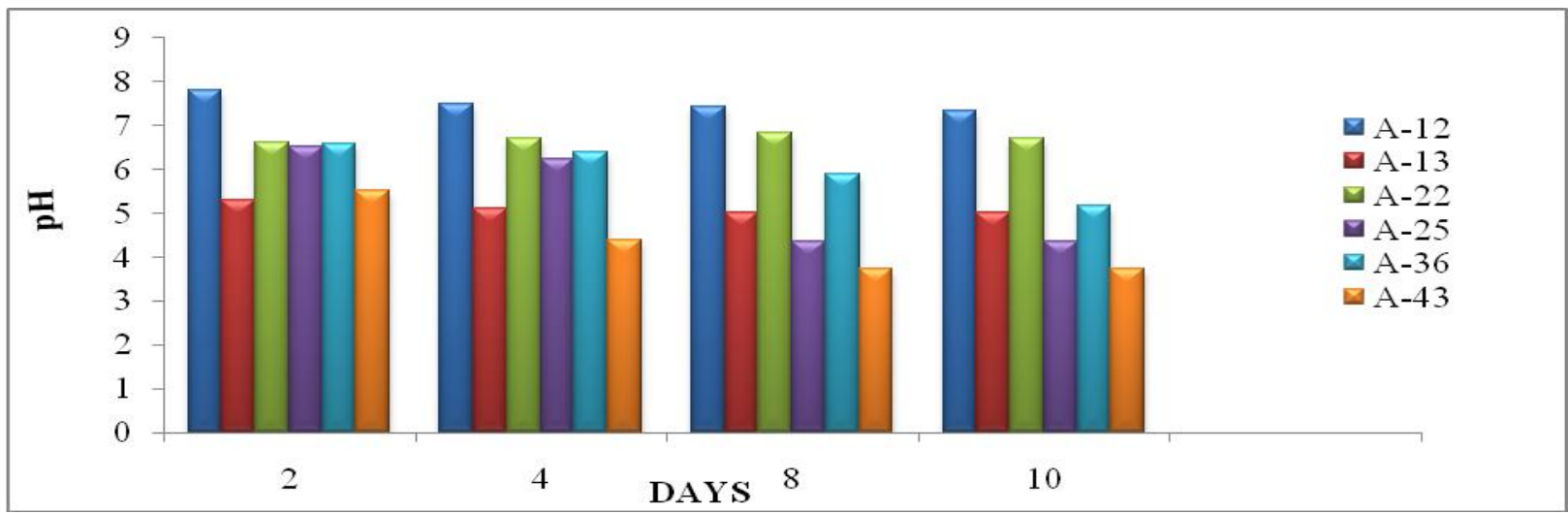

Table.1 Zinc solubilisation by different rhizobacteria at 10 and $20^{\circ} \mathrm{C}$

\begin{tabular}{|c|c|c|c|c|}
\hline \multirow{3}{*}{ Rhizobacterial Isolates } & \multicolumn{4}{|c|}{ Solubilization Efficiency } \\
\hline & \multicolumn{2}{|c|}{ At $20^{\circ} \mathrm{C}$} & \multicolumn{2}{|c|}{ At $10^{\circ} \mathrm{C}$} \\
\hline & $\mathrm{ZnO}$ & $\mathrm{ZnCO}_{3}$ & $\mathrm{ZnO}$ & $\mathrm{ZnCO}_{3}$ \\
\hline A-1 & 55.56 & 116.67 & - & - \\
\hline A-2 & 112.50 & 45.45 & 250.00 & 175.00 \\
\hline A-3 & 287.50 & 380.00 & - & - \\
\hline$A-4$ & 63.27 & 150.00 & - & - \\
\hline A-5 & 125.00 & 111.11 & - & - \\
\hline A-6 & 300.00 & 425.00 & 200.00 & 233.33 \\
\hline A-7 & 85.71 & 112.50 & - & - \\
\hline A-8 & 114.29 & 88.89 & - & - \\
\hline A-9 & 91.67 & 110.00 & 160.00 & 166.67 \\
\hline A-11 & 380.00 & 487.50 & 100.00 & 100.00 \\
\hline A-12 & 575.00 & 583.33 & 290.00 & 280.00 \\
\hline A-13 & 580.00 & 733.33 & 240.00 & 250.00 \\
\hline A-14 & 150.00 & 50.00 & - & - \\
\hline A-15 & 380.00 & 366.67 & - & - \\
\hline A-16 & 212.50 & 300.00 & 225.00 & 120.00 \\
\hline A-17 & 150.00 & 105.13 & - & - \\
\hline A-19 & 437.50 & 500.00 & - & - \\
\hline A-21 & 350.00 & 35.71 & - & - \\
\hline A-22 & 520.00 & 416.67 & 100.00 & 200.00 \\
\hline A-23 & 316.67 & 81.82 & - & - \\
\hline A-24 & 500.00 & 666.67 & - & - \\
\hline A-25 & 485.37 & 240.00 & 233.33 & 90.00 \\
\hline A-27 & 100.00 & 77.78 & - & - \\
\hline A-28 & 124.49 & 78.95 & - & - \\
\hline A-29 & 390.00 & 566.67 & 116.67 & 120.00 \\
\hline A-31 & 73.68 & 60.00 & - & - \\
\hline A-32 & 66.67 & 387.50 & - & - \\
\hline A-33 & 73.33 & 60.00 & - & - \\
\hline A-34 & 450.00 & 81.82 & - & - \\
\hline A-35 & 66.67 & 78.95 & - & - \\
\hline A-36 & 675.00 & 625.00 & 260.00 & 260.00 \\
\hline A-37 & 350.00 & 500.00 & 116.67 & 160.00 \\
\hline A-38 & 103.39 & 122.22 & - & - \\
\hline A-39 & 142.86 & 83.33 & 225.00 & 225.00 \\
\hline A-40 & 42.86 & 115.38 & - & - \\
\hline A-41 & 300.00 & 300.00 & - & - \\
\hline A-42 & 400.00 & 525.00 & - & - \\
\hline A-43 & 966.67 & 800.00 & 280.00 & 260.00 \\
\hline
\end{tabular}

- means absent. 
Table.2 Phosphate solubilization as a function of time by rhizobacterial isolates at $10^{\circ} \mathrm{C}$

\begin{tabular}{cccccc|c}
\hline \multirow{2}{*}{$\begin{array}{c}\text { Rhizobacterial } \\
\text { Isolates }\end{array}$} & \multicolumn{3}{c}{$\begin{array}{c}\text { P-solubilization (mg/100ml) } \\
\text { Incubation period (days) }\end{array}$} & $\begin{array}{c}\text { P- } \\
\text { solubilization } \\
\text { Index(cm) }\end{array}$ \\
\cline { 2 - 5 } A-3 & $\mathbf{3}^{\text {rd }}$ & $\mathbf{6}^{\text {th }}$ & $\mathbf{9}^{\text {th }}$ & $\mathbf{1 2}^{\text {th }}$ & $\mathbf{1 5}^{\text {th }}$ & 2.2 \\
\cline { 2 - 5 } $\mathbf{A - 6}$ & 3.7 & 1.9 & 1.7 & 0.6 & 0.4 & 2.1 \\
$\mathbf{A - 1 2}$ & 0.4 & 1.7 & 4.2 & 2.9 & 7.4 & 4.3 \\
$\mathbf{A - 1 3}$ & 4.8 & 4.6 & 8.1 & 6.3 & 5.2 & 4.1 \\
$\mathbf{A - 1 5}$ & 8.1 & 9.6 & 10.5 & 7.5 & 4.1 & 2.2 \\
$\mathbf{A - 2 2}$ & 0.4 & 1.1 & 2.1 & 4.3 & 6.1 & 2.0 \\
$\mathbf{A - 2 5}$ & 0.5 & 1.4 & 4.2 & 1.0 & 0.4 & 4.3 \\
$\mathbf{A - 2 9}$ & 5.0 & 6.3 & 13.1 & 10.3 & 6.9 & 2.3 \\
$\mathbf{A - 3 4}$ & 1.0 & 0.6 & 2.5 & 6.6 & 6.3 & 3.9 \\
$\mathbf{A - 3 6}$ & 5.1 & 6.3 & 7.8 & 7.2 & 7.5 & 2.5 \\
$\mathbf{A - 4 3}$ & 3.3 & 7.3 & 7.9 & 6.3 & 3.1 & 4.5 \\
\hline
\end{tabular}

Table.3 Phosphate solubilization as a function of time by rhizobacterial isolates at $20^{\circ} \mathrm{C}$

\begin{tabular}{cccccc|c}
\hline \multirow{2}{*}{$\begin{array}{c}\text { Rhizobacterial } \\
\text { Isolates }\end{array}$} & \multicolumn{5}{c}{$\begin{array}{c}\text { P-solubilization (mg/100ml) } \\
\text { Incubation period (days) }\end{array}$} & $\begin{array}{c}\text { P- } \\
\text { solubilization } \\
\text { Index(cm) }\end{array}$ \\
\cline { 2 - 6 } $\mathbf{A - 3}$ & 3.0 & 8.3 & 5.3 & 3.1 & 2.7 & 2.7 \\
$\mathbf{A - 6}$ & 3.1 & 7.0 & 4.3 & 3.2 & 2.9 & 3.7 \\
$\mathbf{A - 1 2}$ & 10.4 & 17.1 & 16.2 & 12.2 & 9.2 & 6.1 \\
$\mathbf{A - 1 3}$ & 8.8 & 21.1 & 11.3 & 10.8 & 8.3 & 6.2 \\
$\mathbf{A - 1 5}$ & 7.2 & 10.9 & 15.3 & 10.1 & 9.8 & 4.4 \\
$\mathbf{A - 2 2}$ & 5.3 & 11.8 & 7.7 & 7.6 & 7.4 & 5.8 \\
$\mathbf{A - 2 5}$ & 13.4 & 23.7 & 18.3 & 15.4 & 11.1 & 6.6 \\
$\mathbf{A - 2 9}$ & 4.3 & 11.4 & 6.2 & 5.3 & 3.7 & 5.4 \\
$\mathbf{A - 3 4}$ & 4.8 & 5.4 & 14.2 & 6.6 & 2.5 & 5.5 \\
$\mathbf{A - 3 6}$ & 9.1 & 19.9 & 12.5 & 9.3 & 8.7 & 5.9 \\
$\mathbf{A - 4 3}$ & 5.7 & 18.9 & 15.8 & 12.0 & 11.1 & 6.4 \\
\hline
\end{tabular}


Table.4 Relative production of IAA equivalents by rhizobacteria

\begin{tabular}{|c|c|c|c|c|}
\hline \multirow{3}{*}{$\begin{array}{c}\text { Rhizobacterial } \\
\text { Isolates }\end{array}$} & \multicolumn{4}{|c|}{ IAA equivalents $(\mu \mathrm{g} / \mathrm{ml})$} \\
\hline & \multicolumn{2}{|c|}{ At $10^{\circ} \mathrm{C}$} & \multicolumn{2}{|c|}{ At $20^{\circ} \mathrm{C}$} \\
\hline & L-TRP (-) & L-TRP (+) & L-TRP (-) & L-TRP (+) \\
\hline A-1 & 2.31 & 4.50 & 2.31 & 10.06 \\
\hline A-2 & 0.60 & 2.37 & 1.04 & 3.82 \\
\hline A-3 & 3.29 & 11.26 & 5.16 & 5.75 \\
\hline A-4 & 4.05 & 3.29 & 2.85 & 4.90 \\
\hline A-5 & 0.76 & 3.61 & 9.18 & 17.23 \\
\hline A-6 & 1.84 & 4.68 & 1.30 & 12.57 \\
\hline A-7 & 2.84 & 3.68 & 2.91 & 15.16 \\
\hline A-8 & 1.48 & 2.16 & 2.19 & 9.92 \\
\hline A-9 & 2.05 & 3.80 & 4.20 & 21.5 \\
\hline A-10 & 0.98 & 3.70 & 2.11 & 7.73 \\
\hline$A-11$ & 3.37 & 5.59 & 1.26 & 5.43 \\
\hline A-12 & 4.51 & 20.21 & 6.77 & 23.61 \\
\hline A-13 & 2.08 & 18.83 & 6.54 & 26.52 \\
\hline A-14 & 3.79 & 6.25 & 7.58 & 21.68 \\
\hline A-15 & 2.72 & 9.25 & 2.44 & 18.64 \\
\hline$A-16$ & 6.23 & 10.25 & 4.13 & 23.25 \\
\hline A-17 & 1.91 & 6.84 & 2.81 & 5.41 \\
\hline$A-18$ & 2.10 & 4.14 & 1.33 & 18.25 \\
\hline A-19 & 3.52 & 6.92 & 3.55 & 21.36 \\
\hline A-20 & 2.04 & 2.48 & 4.62 & 4.38 \\
\hline A-21 & 3.55 & 4.20 & 5.38 & 6.98 \\
\hline A-22 & 7.04 & 18.30 & 2.68 & 23.63 \\
\hline A-23 & 0.78 & 4.21 & 2.94 & 4.53 \\
\hline A-24 & 0.77 & 3.37 & 3.10 & 4.32 \\
\hline$A-25$ & 3.20 & 3.38 & 1.80 & 4.44 \\
\hline A-26 & 1.37 & 3.99 & 4.79 & 6.96 \\
\hline A-27 & 2.58 & 8.22 & 9.31 & 14.15 \\
\hline A-28 & 1.18 & 2.43 & 2.50 & 7.49 \\
\hline A-29 & 3.05 & 5.10 & 1.65 & 2.77 \\
\hline A-30 & 1.42 & 3.87 & 2.36 & 3.87 \\
\hline A-31 & 2.13 & 7.02 & 6.77 & 21.91 \\
\hline A-32 & 0.74 & 3.38 & 3.38 & 9.12 \\
\hline A-33 & 1.18 & 3.91 & 2.78 & 4.25 \\
\hline A-34 & 2.60 & 3.69 & 9.03 & 9.55 \\
\hline A-35 & 2.08 & 2.77 & 5.40 & 9.39 \\
\hline A-36 & 5.21 & 19.25 & 2.96 & 30.77 \\
\hline A-37 & 1.21 & 2.12 & 1.10 & 2.40 \\
\hline A-38 & 12.25 & 35.66 & 26.92 & 39.81 \\
\hline A-39 & 9.12 & 5.85 & 3.38 & 9.63 \\
\hline A-40 & 6.24 & 43.24 & 13.53 & 68.36 \\
\hline A-41 & 0.87 & 3.35 & 2.09 & 4.79 \\
\hline$A-42$ & 3.70 & 8.12 & 4.98 & 11.85 \\
\hline A-43 & 7.04 & 21.62 & 8.26 & 24.83 \\
\hline
\end{tabular}


Table.5 Siderophore Production by rhizobacterial isolates

\begin{tabular}{cccc}
\hline & \multicolumn{3}{c}{ Siderophore Production } \\
\cline { 2 - 4 } Rhizobacterial & & \multicolumn{2}{c}{ Catechol type $(\boldsymbol{\mu g} / \mathbf{m l})$} \\
Isolates & Dia $(\mathbf{c m})$ & 51.2 & $\mathbf{2 0} \mathbf{C}$ \\
\cline { 2 - 4 } $\mathbf{A 1}$ & 1.8 & 55.8 & 96.8 \\
$\mathbf{A - 2}$ & 2.9 & 90.5 & 98.3 \\
$\mathbf{A - 6}$ & 3.4 & 29.0 & 250.4 \\
$\mathbf{A}-11$ & 1.8 & 71.9 & 86.2 \\
$\mathbf{A - 1 2}$ & 3.1 & 76.3 & 105.2 \\
$\mathbf{A - 1 3}$ & 2.1 & 31.2 & 110.6 \\
$\mathbf{A - 1 6}$ & 1.3 & 30.9 & 69.6 \\
$\mathbf{A - 2 9}$ & 2.9 & 64.1 & 74.0 \\
$\mathbf{A - 3 6}$ & 3.0 & 80.6 & 117.9 \\
$\mathbf{A - 4 3}$ & 2.5 & & 225.9 \\
\hline
\end{tabular}

Table.6 Effect of potent rhizobacterial isolates on germination and seedling growth of wheat under axenic conditions

\begin{tabular}{lccccc}
\hline \multicolumn{1}{c}{$\begin{array}{c}\text { Rhizobacterial } \\
\text { isolates }\end{array}$} & $\begin{array}{c}\text { \% } \\
\text { Germination }\end{array}$ & $\begin{array}{c}\text { Root } \\
\text { Length } \\
\text { (cm) }\end{array}$ & $\begin{array}{c}\text { PhP traits } \\
\text { Length } \\
\text { (cm) }\end{array}$ & $\begin{array}{c}\text { Root Fresh } \\
\text { Weight } \\
(\mathbf{m g})\end{array}$ & $\begin{array}{c}\text { Shoot Fresh } \\
\text { Weight } \\
\text { (mg) }\end{array}$ \\
\cline { 2 - 6 } A-43 & 85 & 16.0 & 9.5 & 0.073 & 0.380 \\
$\mathbf{A - 3 6}$ & 80 & 13.3 & 8.7 & 0.081 & 0.416 \\
A-13 & 85 & 13.0 & 9.1 & 0.057 & 0.337 \\
Control & 80 & 11.6 & 6.2 & 0.042 & 0.197 \\
\hline
\end{tabular}

Values represent mean of two replicates with 10 seeds per replication

However at $20^{\circ} \mathrm{C}$, isolate A- $25(23.7 \mathrm{mg} / 100$ $\mathrm{ml}$ ) exhibited maximum P-solubilization followed by A-13, A-36, A-43, A-12, A-22, A-29, A-3 and A-6 (21.1 to $7.0 \mathrm{mg} / 100 \mathrm{ml})$ after 6 days of incubation (Table 3). Two of the isolates (A-15 and A-34) however, exhibited maximum phosphate solubilization after 9 days of incubation (14.2 to 15.3 $\mathrm{mg} / 100 \mathrm{ml}$ ). Thus, a degree of variability in the relative P-solubilization potential of rhizobacterial isolates was observed and found to be temperature dependent.

Indole acetic acid production

A total of 43 selected isolates of Pseudomonas (twenty), Bacillus (nineteen) and Serratia (four) were tested for the quantitative estimation of IAA in the presence and absence of tryptophan. IAA ranged from 2.12 to $43.24 \mu \mathrm{g} / \mathrm{ml}$ after 5 days of incubation at $10^{\circ} \mathrm{C}$ whereas at $20^{\circ} \mathrm{C}$ IAA production ranged from 2.40 to $68.36 \mu \mathrm{g} / \mathrm{ml}$ after 5 days of incubation (Plate 4). IAA production by potent rhizobacterial isolates was more at $20^{\circ} \mathrm{C}$ than at $10^{\circ} \mathrm{C}$. Surprisingly, four isolates A-3, A-17, A-11, and A-29 showed higher IAA production at $10^{\circ} \mathrm{C}$ as compared to $20^{\circ} \mathrm{C}$ (Table 4).

\section{Production of siderophore}

In our study, we found that 27 of the 43 isolates exhibited formation of orange-halos 
on CAS agar, reflecting the transfer of ferric ions from the medium to the siderophores. The isolate A- 6 being the highest producer $(3.4 \mathrm{~cm})$, followed by A-12 $(3.1 \mathrm{~cm})$ and A-36 $(3.0 \mathrm{~cm})$ (Plate 5). Among 27 rhizobacterial isolates, siderophore producing isolates were further tested for catecholate type of siderophores. Out of the 27 isolates producing orange halo on CAS plates, 10 tested positive for production of catechol-type siderophore (29.0 to $90.5 \mu \mathrm{g} / \mathrm{ml}$ ) at $10^{\circ} \mathrm{C}$ and $(69.6$ to $250.4 \mu \mathrm{g} / \mathrm{ml}$ ) at $20^{\circ} \mathrm{C}$ (Table 5). Maximum siderophore production was shown by A-6 $(250.4 \mu \mathrm{g} / \mathrm{ml}$ and $90.5 \mu \mathrm{g} / \mathrm{ml})$ and $\mathrm{A}-43$ $(225.9 \mu \mathrm{g} / \mathrm{ml}$ and $80.6 \mu \mathrm{g} / \mathrm{ml})$ at both temperatures. Isolates A-36, A-13, A-12 and A-2 (117.9, 110.6, 105.2 and $98.3 \mu \mathrm{g} / \mathrm{ml})$ were maximum producers at $20^{\circ} \mathrm{C}$, whereas at $10^{\circ} \mathrm{C}$, isolate $\mathrm{A}-13, \mathrm{~A}-12, \mathrm{~A}-36$ and $\mathrm{A}-43$ (76.3, 71.9, 64.1 and $80.6 \mu \mathrm{g} / \mathrm{ml})$ were maximum producers.

\section{Gibberellic acid production}

On the basis of zinc and phosphate solubilising ability, 18 rhizobacterial isolates were estimated for gibberellic acid production $\left(10\right.$ and $\left.20^{\circ} \mathrm{C}\right)$. All the selected isolates showed gibberellic acid production (Table 6), however, relative variation in GA production ranged from 11.2 to $60.7 \mu \mathrm{g} / \mathrm{ml}$ at $10^{\circ} \mathrm{C}$ and 18.8 to $113.4 \mu \mathrm{g} / \mathrm{ml}$ at $20^{\circ} \mathrm{C}$. The maximum gibberellic acid produced was recorded in the case of A-43 $(60.7 \mu \mathrm{g} / \mathrm{ml})$ followed by A-13, A-36 and A-12 $(50.5,43.4$ and $43.3 \mu \mathrm{g} / \mathrm{ml})$ at $10^{\circ} \mathrm{C}$. Whereas, at $20^{\circ} \mathrm{C}$ isolate $\mathrm{A}-13, \mathrm{~A}-43$, A-12, A-25 and A-10 (113.4,104.8, 97.6, 86.0 and $80.4 \mu \mathrm{g} / \mathrm{ml})$ were maximum GA producers.

\section{Intrinsic Antibiotic Resistance (IAR) spectra of rhizobacterial isolates}

The four rhizobacterial isolates were tested for their reactivity to antibiotics with the understanding that isolates having resistance against large number of antibiotics may compete well in soil and may have broader role in disease resistance.

Rhizobacterial isolates A-43, A-36, A-13 and A-12 were found to be resistant to ampicillin and Tetracycline. Isolate A-13 and A-12 were found to be resistant against streptomycin whereas A-36, A-13 and A-12 were found to be resistant against carbenicillin. However, the isolates A-43 and A-12 were found to resistant against Kanamycin.

Effect of potent rhizobacterial isolates on germination and seedling growth of wheat under axenic conditions

Germination tests were carried out to determine the effect of inoculation with zinc solubilizing rhizobacteria on seed germination. It revealed that under in vitro conditions, seed treatment with PGPR strains improved seedling germination, vigor, emergence and seedling stand as compared to uninoculated control. Maximum germination was recorded with A-43 and A-13 (85\%) followed by A-36 (80\%) which was at par to control (Plate 6).

The increase may be attributed to the IAA producing potential of these two isolates. The improvement in seed germination by PGPR was also reported by Shaukat et al., (2006), they observed that some PGPR increased seed emergence, in some cases achieving increases up to $100 \%$ greater than controls. Isolate A-43 recorded increased root length upto $16 \mathrm{~cm}$, followed by A-36, A-13 as compared to uninoculated control $(11.6 \mathrm{~cm})$.

Maximum root fresh weights was also recorded with A-36 $(0.081 \mathrm{mg} / \mathrm{seedling})$ and A-43 (0.073 mg/seedling) as compared to uninoculated control $(0.042 \mathrm{mg} / \mathrm{seedling})$ (Table 7). This could be due to the plant growth promoting traits acting in synergism. 
The maximum increase $53.2 \%$ in shoot length of wheat seedlings was observed in response to inoculation with rhizobacterial isolate $\mathrm{A}$ 43, followed by A-13 and A-36 (46.8 and 40.3\%). However, maximum shoot fresh weight was found by isolate A-36 (0.41 $\mathrm{mg} / \mathrm{seedling}$ ) followed by A-43, A-13 (0.38 and $0.33 \mathrm{mg} / \mathrm{seedling}$ ), respectively as compared to control $(0.19 \mathrm{mg} / \mathrm{seedling})$. In confirmation to our observations, Ryu et al., (2003) also observed that PGPR treatment increased germination rate and root/ shoot growth, while Dal-Bello et al., (2002) observed that seed bacterization proved a successful method for enhancing biological control of plant disease.

Application of plant growth promoting rhizobacteria, can be a useful component to overcome micronutrient deficiencies and promote plant growth. This study has revealed the multiple abilities of plant growth promotion by low-temperature tolerant rhizobacteria isolates (A-43, A-13, A-12, and A-36). Axenic germination assay revealed the enhancement in seedling emergence, root and shoot length, and weight by A-43, A-36, and A-13. On the basis of their multiple PGP traits (zinc and phosphate solubilization, IAA equivalent, Gibberellic and Siderophore production) and their potential to enhance growth parameter under axenic conditions, it would be prudent to the evaluate these as biofertilizers seeds or soil drench to test for improvement of nutritional conditions and ultimately growth and yield of wheat crops under field conditions.

\section{References}

Ahmad, F. Ahmad, I., Khan, M.S. 2008. Screening of free-living rhizospheric bacteria for their multiple plant growth promoting activities. Microbiol. Res., 163: 173-181.

Arnow, L.E., $1937 . \quad$ Colorimetric determination of the components of 3 , 4-dihydroxyphenylalanine-tyrosine mixtures. J. biol. Chem., 118: 531-537.

Borrow, A., Brian, P.W., Chester, V.E., Curtis, P.J., Hemming, H.G., Henehan, C., Jeffreys, E.G., Lloyd, P.B., Nixon, I.S., Norris, G.L.F., Radley, M., 1955. Gibberellic acid, a metabolic product of the fungus Gibberella fujikuroi: some observations on its production and isolation. J. Sci. Food. Agric., 6: 340348.

Dal-Bello, G.M., Monaco, C.I., Simon, M.R., 2002. Biological control of seedling blight of wheat caused by Fusarium graminaerum with beneficial rhizosphere microorganism. World J. Microbiol. Biotechnol., 18: 627-636.

Desai, S., Kumar, G. P., Sultana, U., Pinisetty, S., Ahmed, S. K., Amalraj, E. and Gopal, R., 2012. Potential microbial candidate strains for management of nutrient requirements of crops. African J. Microbiol. Research 6: 3924-3931.

Edi-Premono, Moawad, M.A., and Vleck, PLG., 1996. Effect of phosphate solubilizing Pseudomonas putida on the growth of maize and its survival in the rhizosphere. Indian J. of Crop Sci., 11: 13-23.

FAOSTAT, 2014. Food and Agriculture Organization of the United Nations, FAOSTAT database. http://faostat.fao.org.

Fasim, F., Ahmed, N., Parsons, R., Gadd, G.M., 2002. Solubilization of zinc salts by the bacterium isolated by the air environment of tannery. FEMS. Microbiol. Let. 213: 1-6.

Gordon, A. S., Weber, R.P., 1951. Calorimetric estimation of Indole acetic acid. Plant. Physiol. 25: 192-195.

Goteti, P.K., Emmanuel, L.D.A., Desai, S. and Shaik, M.H.A., 2013. Prospective zinc solubilising bacteria for enhanced nutrient uptake and growth promotion 
in maize (Zea mays L.). Int. J. Food. Microbiol., 2013.

Jackson, M.L., 1973. Phosphorus determination for soils. In: Soil Chem Analysis. Prentica Hall India Pvt. Ltd, New Delhi. pp. 134-182.

Joshi, D., Negi, G., Vaid, S., Sharma, A., 2013. Enhancement of Wheat Growth and $\mathrm{Zn}$ Content in Grains by Zinc Solubilizing Bacteria. Int. J. Agri. Env. Biotechnol. 6: 363-370.

Khalid, A., Arshad, M., Zahir, Z.A., 2004. Screening plant growth promoting rhizobacteria for improving growth and yield of wheat. J. Appl. Microbiol. 96: 473-480.

King E.O., Ward M.K., Raney, D.E., 1954. Two simple media for the demonstration of pyocyanin and fluorecein. J. Lab. Clin. Med. 44:301307.

Lucy, M., Reed, E., Glick, B.R., 2004. Applications of free living plant growth-promoting rhizobacteria. Review Antonie Van Leeuwenhoek 86: 1-25.

Mehta, S., Nautiyal, C.S., (2001). An efficient method for qualitative screening of phosphate-solubilizing bacteria. Curr. Microbiol. 43: 51-56.

Nadeem, S.M., Ahmad, M., Zahir, A.Z., Javaid A., Ashraf, M., 2014. The role of mycorrhizae and plant growth promoting rhizobacteria (PGPR) in improving crop productivity under stressful environments. Biotechnol. adv. 32: 429-448.

Ramesh, A., Sharma, S.K., Sharma, M.P., Namrata, Y., Joshi, O.P., 2014. Inoculation of zinc solubilizing Bacillus aryabhattai strains for improved growth, mobilization and biofortification of zinc in soybean and wheat cultivated in vertisols of central. India. App. Soil. Ecol. 73: 87-96.

Ryu, C.M., Farag, M.A., Hu, C.H., Reddy, M.S., Wei, H.X., Paré, P.W., Kloepper, J.W., 2003. Bacterial volatiles promote growth in Arabidopsis. Proc. Natl. Acad. Sci. 100: 4927-4932.

Saravanan, V.S., Subramoniam, S.R., Raj, S.A., 2004. Assessing in vitro solubilization potential of different zinc solubilizing bacterial (ZSB) isolates. Braz. J. Microbiol. 34: 121-125.

Schwyn, B., Neilands, J.B., 1987. Universal chemical assay for the detection and determination of siderophore. Anal. Biochem. 160: 47-56.

Shaukat, K., Affrasayab, S., Hasnain, S., 2006. Growth responses oï Triticum aestivum to plant growth promoting rhizobacteria used as a biofertilizer. Res. J. Microbiol. 1: 330-8.

Stein, A. J., 2010. Global impacts of human mineral malnutrition. Plant. Soil. 335: $133-154$.

\section{How to cite this article:}

Aamni Singh and Veena Khanna. 2017. Functional Attributes of Psychrotolerant Rhizobacteria from Wheat (Triticum aestivum L.) Rhizoshpere. Int.J.Curr.Microbiol.App.Sci. 6(11): 20652078. doi: https://doi.org/10.20546/ijcmas.2017.611.244 